\title{
PENGEMBANGAN SISTEM INFORMASI DATA CENTER SEBAGAI PENYEDIA DATA PENYUSUNAN BORANG AKREDITASI
}

\author{
Atin Triwahyuni \\ Jurusan Sistem Informasi STMIK PalComTech \\ Jln. Basuki Rahmat no. 05, Palembang, Sumatera Selatan \\ Telp. 0711-358916 \\ Email : atr.tesla@gmail.com
}

\begin{abstract}
Accreditation is a method of evaluating programs and policies of a college to ensure that the program of study at a college meet certain criteria, which are usually set by the institution / agency accreditation. The problem that often arises is the lack of information that provides a neatly arranged accreditation forms of data compilation. This research is important to do, because it helps reduce data recording repeated in the preparation of the accreditation forms and can speed up the process of preparing the accreditation forms by providing a data center that is packed in an information system. The results showed that the presence of information systems data center accreditation forms can correct accreditation forms of data processing and documentation neat. With the help of the form of office automation system can produce output in the form of a Microsoft Excel file that will facilitate in developing the necessary data in the preparation of the accreditation forms.
\end{abstract}

\section{Keywords: accreditation forms, data center}

Akreditasi adalah metode mengevaluasi program dan kebijakan dari sebuah perguruan tinggi untuk memastikan bahwa program studi di sebuah perguruan tinggi memenuhi kriteria tertentu, yang biasanya ditetapkan oleh lembaga/badan akreditasi. Masalah yang sering kali muncul adalah tidak adanya informasi yang tertata dengan rapi yang menyediakan data penyusunan borang akreditasi. Penelitian ini penting untuk dilakukan, karena sangat membantu mengurangi pencatatan data yang berulang-ulang dalam penyusunan borang akreditasi serta dapat mempercepat proses penyusunan borang akreditasi dengan menyediakan sebuah data center yang dikemas dalam sebuah sistem informasi. Hasil penelitian menunjukkan bahwa dengan adanya sistem informasi data center borang akreditasi dapat memperbaiki pengolahan data borang dan dokumentasi yang tertata rapi. Dengan adanya bantuan berupa office automation dapat menghasilkan output dari sistem berupa file Microsoft Excel yang akan memudahkan dalam menyusun data yang diperlukan dalam penyusunan borang akreditasi.

Kata Kunci: borang akreditasi, data center

\section{PENDAHULUAN}

Penerapan teknologi informasi dan komunikasi dapat meningkatkan kualitas layanan sistem informasi di semua bidang kehidupan. Pengembangan sistem informasi di bidang pendidikan dapat memberikan dukungan informasi kepada proses pengambilan keputusan di semua tingkat administrasi pelayanan di perguruan tinggi.

Akreditasi adalah metode mengevaluasi program dan kebijakan dari sebuah perguruan tinggi untuk memastikan mereka memenuhi kriteria tertentu, yang biasanya ditetapkan oleh lembaga/badan akreditasi. Ketika sebuah perguruan tinggi memenuhi kriteria minimum, mereka diberikan akreditasi. Akreditasi dimaksudkan untuk melindungi perguruan tinggi dan menjamin bahwa perguruan tinggi melakukan mekanisme pembelajaran pada tingkat yang dapat diterima secara nasional.

Masalah yang sering kali muncul adalah tidak adanya informasi yang tertata dengan rapi yang menyediakan data penyusunan borang akreditasi. Padahal program studi di perguruan tinggi setiap periode waktu tertentu misalnya 3 atau 5 tahun mengajukan perpanjangan izin. Jika tidak ada sebuah data center (sumber data) yang dapat dimanajemen 
secara periodik, maka pencatatan akan terjadi berulang-ulang, padahal informasi sebelumnya sangat berguna pada penyusunan borang akreditasi selanjutnya. Penelitian ini penting untuk dilakukan, karena sangat membantu mengurangi pencatatann data yang berulang-ulang dalam penyusunan borang akreditasi serta dapat mempercepat proses penyusunan borang akreditasi. Penawaran otomatisasi sistem informasi data center dilakukan dengan cara membuat sebuah sistem informasi yang menyediakan data yang diperlukan dalam penyusunan borang akreditasi. Sehingga ketika waktu penyusunan borang akreditasi dilaksanakan, data center cukup memberikan data yang dibutuhkan tanpa perlu menginput kembali data-data dari awal. Berdasarkan latar belakang yang diuraikan dalam penelitian ini, rumusan masalah yang akan dipecahkan pada prinsipnya adalah tidak adanya kemudahan dalam penyusunan borang akreditasi. Dengan demikian permasalahan yang akan dimunculkan dalam penelitian ini adalah:

1) Bagaimana merancang sebuah sistem yang mampu menyediakan informasi yang dibutuhkan dalam penyusunan borang akreditasi?

2) Bagaimana data borang akreditasi dapat dimanajemen secara periodik dengan bantuan sistem informasi?

Borang Akreditasi Program Studi merupakan alat atau instrumen untuk mengumpulkan informasi mengenai kinerja Program Studi pada perguruan tinggi negeri, perguruan tinggi kedinasan, perguruan tinggi keagamaan, dan perguruan tinggi swasta dalam rangka pengendalian mutu semua perguruan tinggi di Indonesia. Borang akreditasi terdiri atas seperangkat pertanyaan yang sebagian berupa pertanyaan tertutup, dan sebagian lagi berupa pertanyaan terbuka. Sesuai dengan petunjuk pada setiap butir pertanyaan, maka sebagian dari pertanyaan-pertanyaan dapat dijawab dengan menuliskan jawabannya pada tempat yang disediakan dalam borang akreditasi, sebagian lagi memerlukan lembaran tersendiri (BAN-PT, 2008).

Sebuah Data Center (kadang-kadang dieja datacenter) adalah penyimpanan sentral, baik fisik maupun virtual untuk media penyimpanan, manajemen, dan penghamburan dari data dan informasi diorganisir sekitar badan pengetahuan tertentu atau menyinggung pada bisnis tertentu. Sebagai contoh National Climatic Data Center (NCDC) adalah sebuah data center umum yang merawat arsip dunia terbesar mengenai informasi cuaca (Walat, 2012).

Sebuah sistem informasi tidak harus melibatkan komputer. (Kadir, 2003). Menurut Alter (1992) sistem informasi adalah kombinasi antara prosedur kerja, informasi, orang, dan teknologi informasi yang diorganisasikan untuk mencapai tujuan dalam sebuah organisasi.

Basis data (database) adalah suatu pengorganisasian sekumpulan data yang saling terkait sehingga memudahkan aktifitas untuk memperoleh informasi. Basis data dimaksudkan untuk mengatasi problem pada sistem yang memakai pendekatan berbasis berkas (Kadir, 2003). Menurut Kristanto (2003) mendefinisikan bahwa proses normalisasi meupakan proses pengelompokan data elemen menjadi tabel-tabel yang menunjukan entity dan relasinya.

Office Automation (OA) Sistem mendukung pekerjaan pada suatu perusahaan secara luas, biasanya digunakan untuk meningkatkan aliran pekerjaan dan komunikasi antar sesama pekerja, tidak peduli apakah pekerja tadi berada di satu lokasi yang sama ataupun tidak (Permanaderry, 2012).

\section{METODE PENELITIAN}

Bahan yang digunakan dalam penelitian ini adalah data tentang cara, proses dan prosedur pengisian data borang akreditasi. Dari data tersebut kemudian mendesain perangkat lunak untuk selanjutnya digunakan sebagai acuan dalam input data borang akreditasi. Penelitian ini juga menggunakan studi literatur berupa artikel, buku teks, dan referensi yang dapat menunjang penelitian.

Penelitian ini direncanakan akan membuat suatu rancangan sistem yang dapat menyimpan informasi data isian borang akreditasi. Untuk itu dilakukan langkah-langkah penelitian sebagai berikut :

a) Mendokumentasikan tahapan pencatatan borang akreditasi di level program studi dalam perguruan tinggi. 
b) Menganalisa proses bisnis administrasi data pengisian borang akreditasi. Dari hasil dokumentasi, diperoleh data mengenai prosedur, aturan, dan komponen terkait yang akan dimodelkan dalam perancangan aplikasi yang direncanakan.

c) Melakukan perancangan aplikasi. Analisis sistem dimodelkan ke dalam satu bentuk rancangan sistem.

d) Menganalisa permasalahan yang timbul. Permasalahan yang timbul dalam proses pengisian data borang akreditasi. Dalam hal ini proses pengisian data borang akreditasi dilakukan dengan menyesuaikan standar pengisian borang dari standar 1 sampai standar 7.

e) Mencari dan menerapkan solusi permasalahan. Dari permasalahan yang timbul dalam pengisian data borang akreditasi, maka diperlukan sebuah sistem informasi yang lebih fleksibel dalam hal ini dikembangkan sebuah data center menggunakan perangkat lunak.

f) Membuat kesimpulan penelitian. Dalam proses pencapaian solusi, diharapkan diperoleh kesimpulan yang akan memenuhi tujuan penelitian dan menjawab hipotesis.

Dari sistem konvensional belum ada layanan berupa sistem informasi pengisian data borang akreditasi, kemudian dikembangkan sistem pelayanan yang lebih fleksibel seperti diperlihatkan pada gambar 1 .

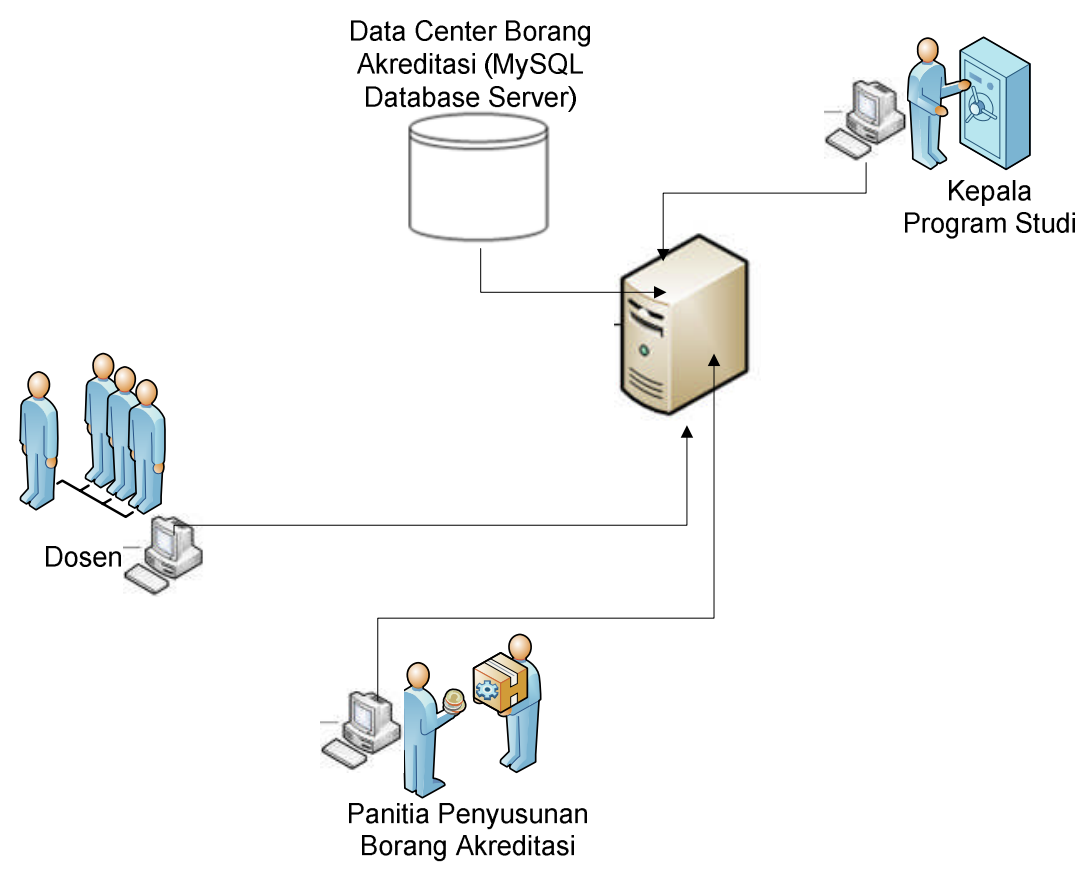

\section{Gambar 1. Model Pengisian Borang Akreditasi Berbasis Sistem Informasi}

Dari gambar 1 digambarkan secara detail mengenai cara kerja dari sistem yang akan dikembangkan. Sistem dibangun dengan menggunakan sebuah database server MySQL yang mampu menampung jumlah data yang besar. Semua pihak yang terlibat dalam penyusunan borang akreditasi menyimpan hasil kerjanya berupa standar 1-7 borang ke dalam database secara terpusat. Secara periodik semua user yang terlibat seperti dosen, panitia, kepala program studi dapat memasukkan data yang diperlukan kapan saja. Dengan harapan pada saat tiba penyusunan borang akreditasi tidak perlu memasukkan data dari awal, karena telah diinput. Dalam rancangan sistem hanya dilakukan simulasi dari salah program studi saja yaitu Sistem Informasi, ketika sistem ini berhasil dalam simulasi maka model sistem dapat digunakan secara langsung. Artinya tidak membuat simulasi untuk semua program studi, mengingat secara model sistem sama hanya lokasinya saja yang berbeda.

Penelitian ini akan mengadopsi rekayasa perangkat lunak model waterfall. Model ini merupakan model yang paling banyak dipakai oleh para pengembang software. Ada lima tahap dalam model waterfall, yaitu: Requirement Analysis, Sistem Design, Implementation, Integration dan Testing, Operations dan Maintenance. Sesuai dengan namanya waterfall (air terjun) maka tahapan dalam model ini disusun bertingkat, setiap tahap dalam model ini dilakukan berurutan, 
satu sebelum yang lainnya (lihat tanda anak panah) pada Gambar 2. Selain itu dari satu tahap kita dapat kembali ke tahap sebelumnya.

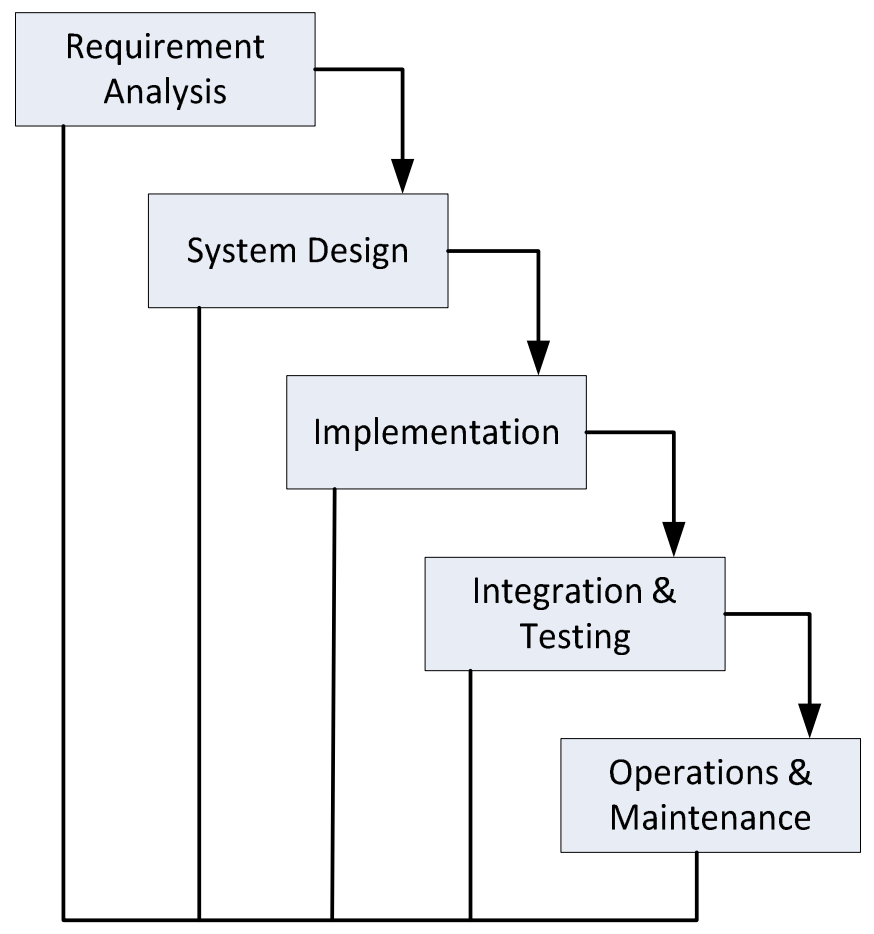

Gambar 2. Tahapan Model Waterfall

Sistem yang dikembangkan merupakan simulasi dari sistem pencatatan pengisian borang akreditasi. Alur sistem pecatatan data dapat digambarkan pada gambar 3 .

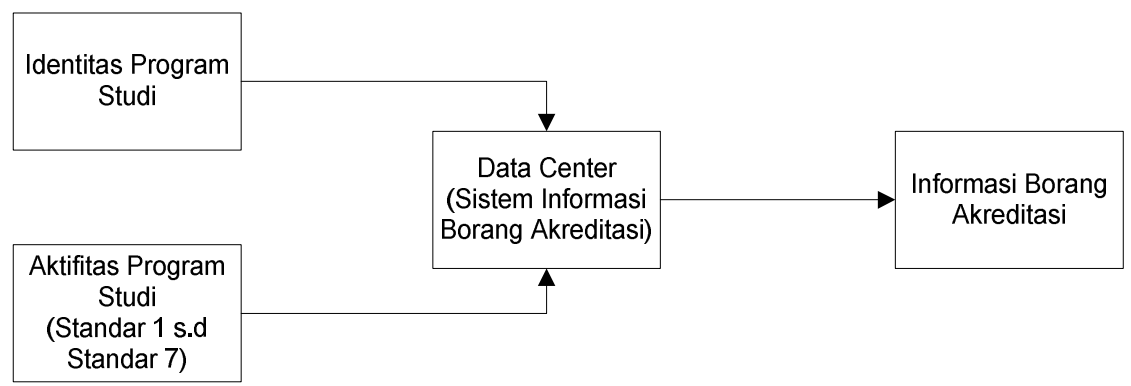

Gambar 3 Alur Data Pengisian Borang Akreditasi

\section{HASIL DAN PEMBAHASAN}

3.1. Hasil

Penelitian ini menghasilkan perangkat lunak yang dibangun dalam lingkungan client/server dengan model visual/desktop application, serta pengujian berupa proses entri data ke dalam sistem untuk selanjutnya dihasilkan output berupa file excel dengan bantuan office automation. Sistem yang dikembangkan meniru dari sistem pencatatan borang akreditasi yang selama ini sudah dilakukan. Selanjutnya hasil sistem pencatatan data yang telah terekam ke dalam sistem akan menjadi sebuah data center yang sewaktu-waktu dapat dicetak. Pencatatan data borang akreditasi ini hanya dibatasi pada proses pencatatan standar 3 sampai dengan standar 7 berupa data timeseries dan tabulasi. Untuk data yang berupa narasi atau deskriptif tidak dimasukkan ke dalam sistem. Hal ini dengan pertimbangan begitu kompleksnya pencatatan data borang akreditasi.

Perbandingan sistem pelayanan yang lama terhadap sistem pelayanan yang baru seperti terlihat pada tabel 1 . 
Tabel 1. Perbandingan sistem lama dengan sistem baru

\begin{tabular}{|l|l|l|}
\hline \multicolumn{1}{|c|}{ Pembanding } & \multicolumn{1}{|c|}{ Sistem lama } & \multicolumn{1}{c|}{$\begin{array}{c}\text { Sistem baru } \\
\text { (interoperabilitas) }\end{array}$} \\
\hline Proses & $\begin{array}{l}\text { Mengumpulkan data borang } \\
\text { akreditasi dengan } \\
\text { mengumpulkan berkas- } \\
\text { berkas borang akreditasi. }\end{array}$ & $\begin{array}{l}\text { Setiap periodik dapat dientri } \\
\text { ke dalam sistem dan setiap } \\
\text { saat bisa diakses sebagai } \\
\text { data center. }\end{array}$ \\
\hline Proses Administrasi & $\begin{array}{l}\text { Dikumpulkan dalam } \\
\text { ruangan } \\
\text { penyusunan kepanitian } \\
\text { akreditasi. }\end{array}$ & $\begin{array}{c}\text { borang } \\
\text { Entri data ke dalam sistem. }\end{array}$ \\
\hline Layanan & Kompleks dan lengkap & Terbatas pada fitur tertentu \\
\hline Pengembangan sistem & Paper Based & $\begin{array}{l}\text { Penambahan layanan dari } \\
\text { segi aplikasi. }\end{array}$ \\
\hline
\end{tabular}

Dalam sistem yang telah dikembangkan panitia penyusunan borang akreditasi cukup memasukkan data isian borang akreditasi ke dalam sistem. Misalnya memasukkan data profile mahasiswa dan lulusan, dapat dilihat pada gambar 4. Setelah proses entri data selesai, selanjutnya dapat dicetak untuk dikonversi menjadi file excel.

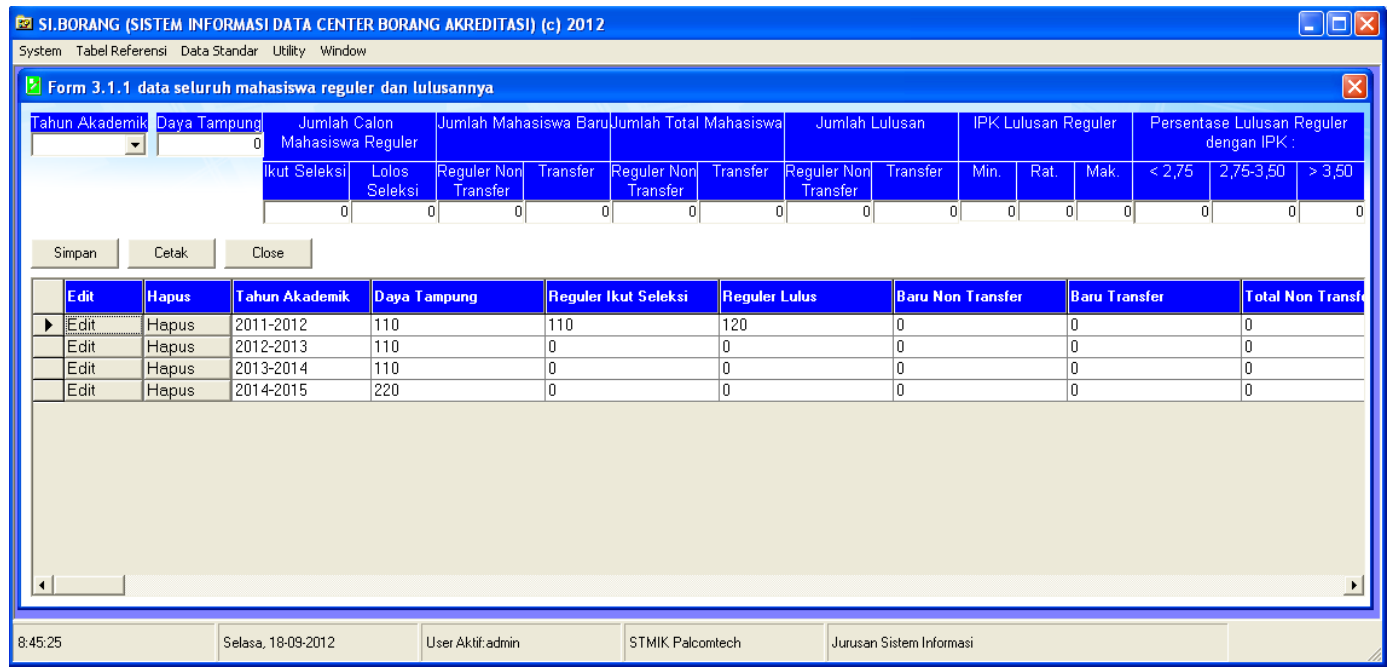

\section{Gambar 4. Menu Standar 3.1.1 Profile Mahasiswa dan Lulusan}

Setiap data standar yang telah dimasukkan selanjutnya akan menjadi sebuah data center yang siap untuk ditampilkan hasilnya setiap periode tertentu. Proses pencetakan data dimasukkan ke dalam file excel sebagai output laporan. Proses output menjadi file excel ini menggunakan bantuan office automation sehingga dengan mudah dikonversi datanya dari MySQL menjadi file Excel.

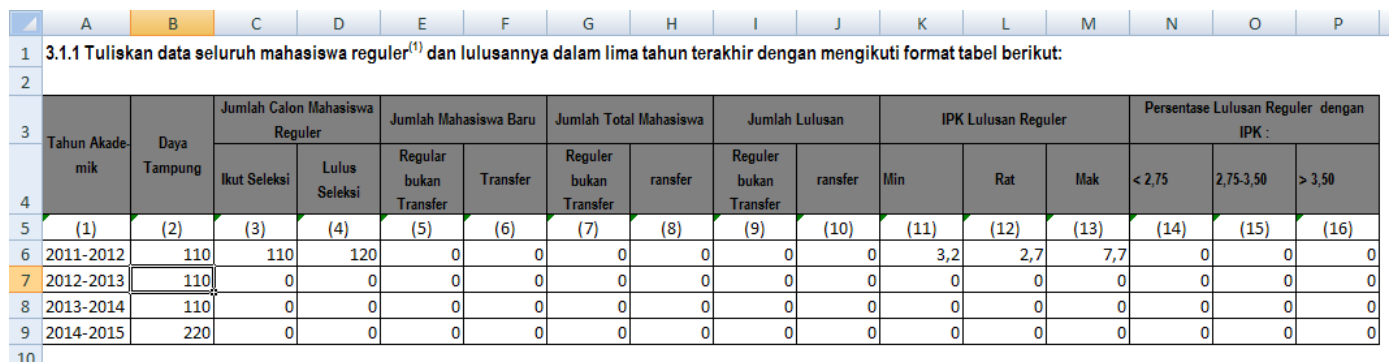

Gambar 5. Office Automation 
Secara garis besar proses input data ke dalam sistem dilakukan dengan proses yang sama untuk memudahkan dalam input data dan output hasil.

\subsection{Pembahasan}

Dalam hasil penelitian tidak semua form ditampilkan mengingat begitu kompleks dan banyaknya form yang telah dihasilkan dari sistem. Pada prinsipnya proses input data dilakukan dengan proses yang tidak jauh berbeda untuk memudahkan dalam proses input data dan menghasilkan output, sehingga pengguna akan berinteraksi dengan user interface menggunakan tombol-tombol pada form pengisian standar. Berikut beberapa keunggulan yang dapat ditawarkan dalam hasil penelitian :

a. Proses entri data dapat dilakukan secara serentak dan berkesinambungan. Serentak dalam arti siapapun yang punya akses ke dalam sistem dapat memasukkan data yang valid. Berkesinambungan berarti kapanpun dijumpai data terbaru dapat segera dimasukkan ke dalam sistem.

b. Hasil dari sistem berupa data center, yaitu dimana data borang akreditasi tersimpan secara terpusat dalam database MySQL.

c. Output yang dihasilkan dari sistem berupa file excel yang diperoleh dengan proses office automation, yaitu proses interaksi antara aplikasi Office dalam hal ini MS. Excell dengan program aplikasi MS. Visual Basic 6.

\section{KESIMPULAN DAN SARAN}

\subsection{Kesimpulan}

Setelah penelitian ini selesai dilakukan, selanjutnya dapat disimpulkan bahwa tersedianya model sistem informasi data center penyusunan borang akreditasi diharapkan mampu memberikan kemudahan untuk memperoleh data borang akreditasi. Kemudahan yang diperoleh berupa keleluasaan mendapatkan informasi borang akreditasi tanpa harus mencatat ulang setiap aktifitas program studi yang dituangkan dalam standar 1 s.d. 7. Agar implementasi sistem ini dapat terlaksana dengan baik perlu diperhatikan faktor teknis dan non-teknis yang dapat mempengaruhi keberhasilan. Pada umumnya faktor non-teknis lebih dominan dibandingkan faktor teknis, oleh karena itu pemahaman mendalam terhadap faktor non-teknis sangat diperlukan ketika merancang dan mengimplementasikan sistem ini.

\subsection{Saran}

Sejauh ini penelitian baru dapat menghasilkan perangkat lunak sistem informasi untuk menyimpan data borang akreditasi yang dapat secara otomatis menghasilkan output berupa keluaran informasi penyusunan borang akreditasi. Untuk penelitian lanjutan dapat dikembangkan sebuah mekanisme tersedianya fasilitas untuk menyimpan dan menghasilkan dokumen-dokumen pendukung yang telah tersimpan datanya. Sebagai contoh jika ada informasi berupa pelatihan yang dilakukan oleh dosen tertentu, maka dalam sistem telah disediakan fasilitas penyimpanan bukti fisik berupa piagam ataupun berkas pendukung terlaksananya kegiatan pelatihan tersebut. Hal seperti ini dapat dilakukan untuk arah penelitian berikutnya.

\section{DAFTAR PUSTAKA}

Alter, Steven. 1992. Information Sistem: A Management Perpective. The Benjamin/Cummings Publishing Company Inc.

BAN-PT. 2008. Buku IV Panduan Pengisian Borang Akreditasi Program Studi Sarjana. Jakarta : Departemen Pendidikan Nasional

Kadir, Abdul. 2003. Pengenalan Sistem Informasi. Yogyakarta: Penerbit Andi Offset

Kristanto, Hariyanto, 2003. Perancangan Sistem Informasi dan Aplikasinya. Yogyakarta : Gava Media.

Permanaderry. 2012. Pengertian Office Automation. http://permanaderry.wordpress.com/kumpulan-tugas/pengertian-office-automation/ diakses pada tanggal 17 September 2012.

Walat, Tom. 2012. Search Data Center. Capacity Planning. http://searchdatacenter.techtarget.com/ diakses pada tanggal 24 maret 2012. 